\title{
The Contribution of Tourist Attraction, Accessibility and Amenities in Creating Tourist Loyalty in Indonesia
}

\author{
Tri Palupi Robustin, ${ }^{1 *}$ Raden Andi Sularso, ${ }^{2}$ Imam Suroso, ${ }^{3}$ DiahYulisetiarini ${ }^{4}$ \\ ${ }^{1}$ Doctoral Student, Faculty of Economic \& Business University of Jember, Indonesia \\ ${ }^{2}$ Raden Andi Sularso, Promoter and lecturer at Jember University, Indonesia \\ ${ }^{3}$ Imam Suroso, Co- Promotor and lecturer at Jember University, Indonesia \\ ${ }^{4}$ DiahYulisetiarini, Co-Promotor and lecturer at Jember University, Indonesia
}

\section{ABSTRACT}

Objective - The Pulau Merah Beach is the most beautiful beach and enjoys number one ranking from the other seven beaches. The unique beach of Pulau Merah in Banyuwangi is so popular among the people of East Java, it is also one of the destinations favored by foreign tourists, particularly for surfing. The Pulau Merah Beach is uniquely placed in a small hill located close to the shoreline. The Pulau Merah beach has a 200-meter-high hill and this reddish color causes the beach to be known as the Pulau Merah Beach. This study aims to determine the partial and simultaneous effects of tourist attraction, accessibility, and amenities on tourist loyalty on the Pulau Merah beaches.

Methodology/Technique - This research is a quantitative study. The sample includes 80 tourists visiting Pulau Merah Beach. The data is analyzed using a multiple regression analysis with the SPSS Program.

Findings - The results of the study show that tourist attraction, accessibility, and amenities have a significant, partial and simultaneous effect on tourist loyalty.

Novelty - Attractiveness, accessibility, and amenities have a significant influence on the satisfaction of tourists.

Type of Paper: Empirical.

Keywords: Attraction; Accessibility; Amenities; Tourist Loyalty; Pulau Merah Beach.

JEL Classification: Z3, Z32, Z39.

\section{Introduction}

\subsection{Background}

Banyuwangi Pulau Merah Beach is a popular tourist destination for domestic and foreign tourists, due to its cleanliness, beauty of the charm of the beach. Banyuwangi is a very wealthy part of the world and is well known around the globe.

\footnotetext{
* Paper Info: Revised: July 22, 2018

Accepted: December 4, 2018

* Corresponding author: Tri Palupi Robustin

E-mail: tripalupirobustin@gmail.com

Affiliation: Student Doctoral Faculty of Economic and Business, University Of Jember, Indonesia.
} 
Nearly half of the Banyuwangi region is surrounded by beaches, including Pulau Merah Beach, located on the southern tip of Banyuwangi Regency. One of the attractions of Pulau Merah Beach is its waves which are popular among surfers. The Banyuwangi Regency Government has held regular surfing events at this beach with participants from over 20 countries around the world. Pulau Merah Beach is ranked one among the other seven beaches. Pulau Merah Beach also generates the most profits compared to the other beaches. Between 2015 and March 2016, Pulau Merah Beach contributed Rp. 251.3 million in tax to the regional government (www.surya.co.id).

Table 1.1 Number of Tourist Visits to Pulau Merah Beach

\begin{tabular}{cccccc}
\hline No & Type of tourist & Year 2014 & Year 2015 & Year 2016 & Total \\
\hline 1 & Foreign Tourist & 5.048 & 6.381 & 3.620 & 15.049 \\
2 & Domestic Tourist & 336.431 & 337.375 & 253.868 & 967.674 \\
\hline & Jumlah & 341.479 & 383.756 & 257.488 & 982.723 \\
\hline
\end{tabular}

Source: Banyuwangi Regency Tourism and Culture Office

Based on Table 1.1 above, the number of visitors to Pulau Merah Beach increases from year to year experienced increases (as shown in 2014 the number of visitors was 341,479, in 2015 the number of visitors rose to 383,756). However, this number does decline at some points (in 2016 the number of visitors dropped to 257,488 ). The total number of visitors to foreign tourists was 15,049 and for domestic tourists it was 967,674, so the total number of visitors to Pulau Merah Beach between 2014 to 2016 was 982,723.

In addition to tourist attractions and accessibility, tourists also look for amenities that support their trip. To fulfill the trip, various facilities are needed. Tourist attractions may entice tourists to a destination, but the tourists also need facilities, food and drinks ( Mill, 1990, p. 24). Tourism is one of the key industries in the nation's economy and the economy of the local community. Economic tourism is very beneficial for the community if it is supported by the quality of the environment, a clean destination, a friendly climate, a friendly society, and multicultural harmony.

Destination sustainability depends on the number of repeat visits and a strong relationship between tourist loyalty and profitability ( Chon \& Ro, 2006, p. 41-58). The factors that influence destination loyalty are the attractiveness of the destination, familiarity with the destination, overall satisfaction, destination image, perceived quality and service, perceived value, and tourist experience (Lai, et al. 2009, p. 980). Customer satisfaction, loyalty and value are the most relevant factors of tourist satisfaction and loyalty. The growth of the tourism industry depends on the satisfaction, length of stay, returning visits and word-of-mouth recommendations of tourists (Hasan, 2015, p. 364). Kotler and Keller (2009, p. 138) state that loyalty is a commitment to buy a product or service in the future.

\subsection{Research Questions}

The following questions are addressed in this study:

1. How does attraction affect tourist loyalty at Pulau Merah Beach Tourism in Banyuwangi Regency?

2. How does accessibility affect tourist loyalty at Pulau Merah Beach Tourism in Banyuwangi Regency?

3. How do amenities affect tourist loyalty at Pulau Merah Beach Tourism in Banyuwangi Regency?

4. How does attraction, accessibility, and amenities simultaneously affect tourist loyalty at Pulau Merah Beach Tourism in Banyuwangi Regency? 


\section{Literature Review}

\subsection{Tourism Products}

As far as the tourist is concerned, a product includes the complete experience from the time they leave their home to the time they return (Middleton, 2009, p. 120). Gamal Suwantoro (2007, p. 75), states that a tourist product is the overall service gained and perceived or enjoyed by tourists. Raju (2000, p. 55) further states that the quality of tourism products and services is divided into five components, namely: attraction, transport, accommodation, support and auxiliary services, physical and communication infrastructure. Middleton (2009, p. 123) states that there are five tourism products, namely: attraction of destination and environment, destination and service facilities, accessibility in destination, destination image, and price. Mason (2000, p. 46) and Poerwanto (1998, p. 53) develop the following components of tourism products:

1. Attractions, namely tourist attraction, that is natural, cultural and man-made destinations such as festivals or performing arts.

2. Accessibility, namely the ease of reaching a tourist destination.

3. Amenities, namely facilities for obtaining pleasure, for example: accommodation, cleanliness and hospitality (tangible and intangible products).

4. Networking, which is a network of cooperation relating to products offered both locally, nationally and internationally.

\subsection{Attraction}

Tourism attraction refers to tourism object, however, according to the Indonesian government regulations introduced in 2009, tourism objects are no longer relevant to a tourist destination. Below are some definitions of Tourist Attraction according to the experts:

1. Based on the Law of the Republic of Indonesia Number 10 in 2009 , tourist attractions are everything that has a unique, value in the form of natural, cultural, and man-made diversity that is targeted or visited by tourists.

2. Yoeti in his 1985 book "Introduction to Tourism" states that tourist attractions is everything that attracts people to visit a certain area.

3. Pendit in his 1994 book "Tourism Science" defines tourist attractions as everything that is interesting and worth visiting and seeing.

Every tourism destination has a different appeal. Different types of tourist attractions are listed below:

1. Natural tourist attractions, all forms of attractions possessed by nature, for example: seas, beaches, mountains, lakes, valleys, hills, waterfalls, canyons, rivers, forests.

2. Man-made tourist attractions, including cultural tourist attractions, for example: dances, puppet shows, traditional ceremonies, songs, ritual ceremonies and tourist attractions which are the work of copyright, for example: building art, sculptures, carvings, paintings.

\subsection{Accessibility}

According to Suyadana and Oktavia (2015, p. 45) there are also less important factors that do not have a large impact on tourist satisfaction and loyalty, such as accessibility factors, which refers to the ease of access to facilities, which is sometimes overlooked by tourists when planning trips. Accessibility includes: 
1. Infrastructure: roads, car parks, trains, airports, seaports, and others.

2. Transportation facilities: speed and availability of various public transportation.

3. Operations: travel routes, service frequency, and costs including toll road costs.

4. Government regulations: regulations on transportation operations.

\subsection{Amenities}

Mason (2000, p. 46) and Poerwanto (1998, p. 53) state that amenities refers to the facilities used to obtain pleasure, for example: accommodation, cleanliness and hospitality (tangible and intangible products). To meet the travel needs of tourists, various facilities are needed, such as transportation, accommodation facilities, eating and drinking facilities and other supporting facilities. This component cannot be separated from the infrastructure component, which guarantees the availability of complete facilities.

\subsection{Customer Loyalty}

Kotler and Keller $(2009$, p. 138) stated that loyalty is a commitment to purchase a product or service in the future. Loyalty, according to Tjiptono (2011, p. 481) refers to repurchasing behavior. According to Griffin (2002, p. 4) "loyalty is defined as non-random purchase expressed over time by some decision making units". Based on that definition, loyalty refers to more than the decision-making behavior of an individual. According to Griffin (2005, p. 31) loyal customers have the following characteristics:

1. Customers purchase products or services repeatedly;

2. Customers build relationships with the products and/or brands;

3. Customers are likely to recommend the product or brand to another person; and

4. Customers do not purchase competitor brands.

\section{Research Methodology}

This research is conducted using survey research. The purpose of this study is to explain the relationship between the chosen variables. The population of this study includes tourists who have visited Pulau Merah Beach Banyuwangi District. The sampling technique used is purposive sampling. The method of determining the sample size is the method developed by Roscoe in his book "Research Methods for Business" (1982, p. 253 ) as quoted in Sugiyono (2009, p. 129), that is multivariate analysis where the number of sample members is minimal (10), including the number of independent and dependent variables. The analysis used in this research is multivariate analysis, that is multiple linear regression analysis, consisting of 4 (four) variables. Hence, the sample size taken is at least $=20 \times 4$ variables $=80$ sample members.

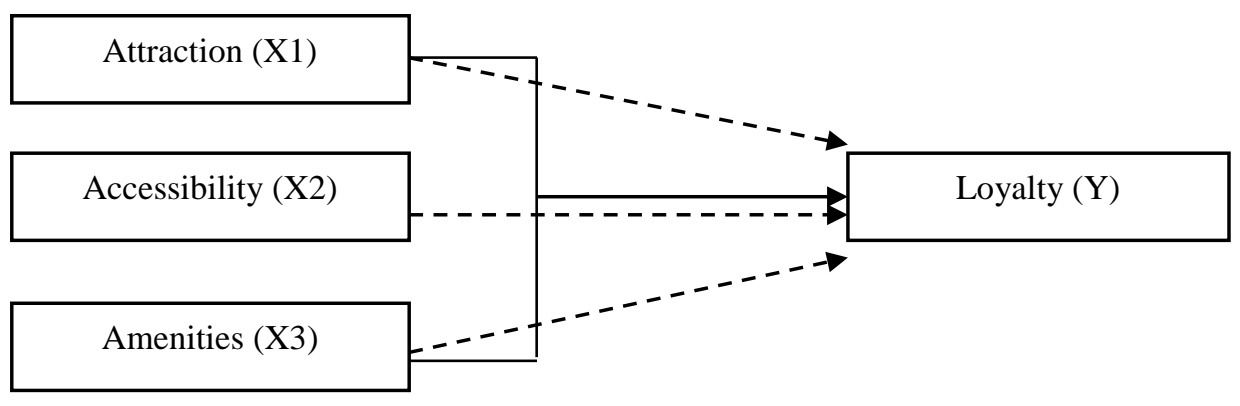

Picture 1. Research Model 


\section{Results}

The multiple linear regression testing is used to understand the level of influence of the independent variables (tourist attraction, accessibility, amenities) on the dependent variable (loyalty). Based on testing with the help of SPSS for Windows 17.0 program, the results are presented in the following table.

Table 4.1 Results of Multiple Linear Regression Calculations

\begin{tabular}{ccccc}
\hline Variable & Coef. Regress. & thitung & Sig. & Decision \\
\hline Constants & $-0,881$ &,- 0781 & 0,437 & - \\
Attraction (X1) & 0,226 & 2,530 & 0,013 & Significant \\
Accessibility (X2) & 0,351 & 4,425 & 0,000 & Significant \\
Amenities (X3) & 0,294 & 4,119 & 0,000 & Significant \\
\hline & $\mathrm{R}$ & & & 0,785 \\
& R Square & & & 0,617 \\
& F Count & & 40,776 \\
Sig & & & 0,000 \\
& $\mathrm{~N}$ & & 80 \\
\hline
\end{tabular}

Based on Table 4.1 above, it can be seen that the value of the t count for X1 $(2,530), \mathrm{X} 2(4,425), \mathrm{X} 3$ $(4,119)$ and probability values (P value) $<0,05$, which means that attraction, accessibility, and facilities have a partial and significant effect on tourist loyalty at Pulau Merah Beach. The calculated $F$ value is 40,776 and the probability value ( $\mathrm{P}$ value) is $<0.05$ or $(0.000<0.05)$, which means that attraction, accessibility, and amenities have a significant and simultaneous effect on tourist loyalty at Pulau Merah Beach. The value of the multiple determination coefficient (R2) is 0.617 , which means that $61.7 \%$ of the changes in tourist loyalty are influenced by attraction, accessibility, and amenities while the remaining $38.3 \%$ is caused by other factors such as service quality, promotion, price and others.

\section{Discussion}

\subsection{The Effect of Attraction on Tourist Loyalty}

The results of the regression test show that tourist attraction has a positive and significant effect on satisfaction. This means that tourist attraction to Pulau Merah Beach will encourage tourist loyalty, thereby supporting H1. Tourist attraction refers to anything that has charm, uniqueness and a high value, which entices tourists to see a certain destination. Hence, the tourist attraction offered by the Pulau Merah Beach is a natural tourist attraction (natural attraction). In this context, the marketing of tourist attraction is an element of the product. Tourist attraction is the main motivation for visitors to visit a particular destination. In addition, tourist attraction can also motivate visitors to return to a destination. The results of this study are inconsistent with research by Eusebio and Vieira (2011), Mohamad et al. (2012) and Frangos et. al. (2014), which state that attraction affects tourist loyalty. 


\subsection{The Effect of Accessibility to Tourist Loyalty}

The regression test results show that accessibilities has a positive and significant effect on tourist loyalty with a coefficient of 0.351 . Based on these results, $\mathrm{H} 2$ is accepted. This means that accessibility to Pulau Merah Beach is good, and transportation to and from is considered easy. The findings of this study support the research of Eusebio and Vieira (2011), Mohamad et al. (2012) and Al-Ababneh (2013) which state that tourist accessibility has an effect on tourist loyalty. However, these findings are inconsistent with research by Chen and Tsai (2007), which states that accessibility does not affect tourist loyalty

\subsection{The Effect of Amenities on Tourist Loyalty}

The results of the regression test show that facilities also have a positive and significant effect on satisfaction. This means facility factors such as the availability of hotels or inns, the availability of food stalls, the availability of equipment rentals (e.g. mats, tires, boats), the availability of places of worship for tourists, and the availability of clean and comfortable toilets is a factor that determines the satisfaction of tourists (Sammeng, 2001, p. 39). According to Yoeti (2003, p. 56), tourist facilities include all facilities that function to meet the needs of tourists staying at a tourist destination. If the tourist facility can provide satisfaction to visitors, then this will stimulate tourist satisfaction. According to Mill (2000, p. 30), "Tourist facility is a support service that is always ready to be utilized by the tourists and the service offers quality and price in accordance with the needs of tourists". These findings are consistent with research by Marek Nowacki (2010), Mukhles Al-Ababneh (2013) and Valentine Della Corte et al. (2014).

\subsection{The Effect of Attraction, Accessibility and Amenities on Tourist Loyalty}

This discussion is related to the test results of the 4th hypothesis which states that attractiveness, facilities, and accessibility significantly affect the satisfaction of tourists. The results show that attractiveness, facilities, and accessibility have a simultaneously affect on the satisfaction of tourists at Papuma Beach. Based on these results, it can be said that attraction, facilities, and accessibility influence tourist satisfaction, however, the results also suggest that accessibility does not affect the satisfaction of tourists. Based on the simultaneous test, the results of the coefficient of the determination doubled (R2) is equal to 0.646 , which means that there is a $64.6 \%$ change of satisfaction influenced by the variables of tourist attraction, facility, and accessibility, while the remaining $35.4 \%$ is caused by other factor such as accommodation, quality of service, and others not included in the regression equation.

\section{Conclusion}

Attractiveness, accessibility, and amenities have a significant influence on the satisfaction of tourists. Therefore, tourist attraction, facilities, and accessibility simultaneously encourage customer loyalty. Future research may adopt the following improvements: For future studies concerning Pulau Merah Beach, researchers must pay close attention to the components related to these factors, including: attraction, accessibilities, and amenities. Future research should include more variables such as service quality, promotion, price, etc. to enable a more comprehensive finding.

\section{References}

Al-ababneh, Mukhles. (2013). Service Quality and its Impact on Tourist Satisfaction. Journal of Contemporary Research in Business, 4(12). 
Arli, Erdal and Gokce Cicek Cehyun. (2014). The Effect of Service Quality Perceptions of Turkish Cruise Tourists on Their Behavioral Intention and Satisfaction. International Journal of Management Sciences and Business Research, 3, 2226-8235.

C. C. Frangos et al. (2015). Tourist Loyalty is All About Prices, Culture and the Sun: A Multinomial Logistic Regression of Tourist Visiting Athens. Procedia-Social and Behavioral Sciences, 175, 32-38.

Christie Mill, Robert. (1990). Tourism: The International Business. New Jersey: Prentice Hall.

Della Corte, Vallentinaet al. Customer Satisfaction in Tourist Destination: The Case of Tourism Offer in The City of Naples. Journal of Investment and Management, 39-50.

Eusebio, Caleste and Armando Luis Vieira. 2011. Destination Attributes Evaluation, Satisfaction and Behavioural Intentions: A Structural Modelling Approach. International Journal of Tourism Research.

$\mathrm{Fu}$ Chen, Ching and Dung Chun Tsai. 2007. How Destination Image and Evaluative Factors Affect Behavioral Intentions. Journal Elsevier Tourism Management, 28, 1115-1122.

Gengqing, Chi. 2005. A Study of Developing Destination Loyalty Model. (Dissertation) Submitted to the Faculty of the Graduate Collage of the Oklahoma State University in Partial Fulfilment of the Requirements for the Degree of Doctor of Philosophy.

Griffin, Jill. 2002. Customer Loyalty How To Earn It, How To Keep It. Kentucky: McGraw-hill.

Griffin, Jill. 2005. Customer Loyalty: Grow and Maintain Customers. Jakarta: Erlangga.

Hasan, Ali. 2015. Tourism Marketing. Yogyakarta: CAPS.

Kotler, Philip. 2009. Marketing Management, Volume 1. Indonesian Edition. Jakarta: PT Index.

Kozak, M. et al. 2001. Comparative Assessment of Tourist Satisfaction with Destinations Across Two Nationalities. Tourism Management, 391-401.

Lai, F., Griffin, M. and Babin, B.J. 2009. How Quality, Value, Image, and Satisfaction Create Loyalty at a Chinese Telecom. Journal of Business Research, 62(10), 980-986.

Medlik, S. and Middleton, V. T. C. (1973). Product Formulation in Tourism. Tourism and Marketing, 13.

Li, X., Cheng, C., Kim, H. and Petrick, J. F. (2008). A Systematic Comparison of First Time and Repeat Visitors via a Two-phase Online Survey, Tourism Management, 29, 278-293.

Mahadzirah, Mohamad. (2011). A Structural Model of Destination Image, Tourists Satisfaction and Destination Loyalty. International Journal of Business and Management Studies, 3(2).

Mahadzirah, Mohamad, et al. (2012). Tourist Evaluation of Destination Image and Future Behavioural Intention: The Case of Malaysia. Journal of Management and Sustainability, 2(1).

Middleton, V. and Clarke, J. (2001). Marketing in Travel and Tourism, 3rd edition, Elsevier.

Middleton, et al. (2009). Marketing Travel and Tourism. Fourth Edition, Elsevier.

Nowacki, Marek. 2010. The Quality Attractions and The Satisfaction, Benefits and Behavioural Intentions of Visitors: Verification of A Model. Journal Tourism, 20(1).

Oka A. Yoety. (2008). Marketing Tourism. PT. Pradnya Paramitha, Jakarta.

Raju. (2000). Tourism Marketing and Management. 1st edition, Manglam Publications.

Roscoe, J.T., 1975. Fundamental Research Statistic for the Behavioural Sciences. New York: Holt, Rinehart and Winston, Inc. hal: 189-197.

Sugiyono. 2009. Business Research Methods. CV. Alfabeta. Bandung.

Suanmali, S. (2014). Factors Affecting Tourist Satisfaction: An Empirical Study in the Northern Part of Thailand. In SHS Web of Conferences (Vol. 12, p. 01027). EDP Sciences.

Suryandana, M. Liga dan Vanny Octaviana. 2015. Introduction to Tourism Marketing. Bandung: Alfabeta

Badarab, F., Trihayuningtyas, E., \& Suryadana, M. L. (2017). Tourism Destination Development Strategy in the Togean Islands, Central Sulawesi Province. Tourism \& Hospitality Essentials (THE) Journal, 7 (2), 97-112.

Um, S., Chon, K., \& Ro, Y. 2206. Antecedents of Revisit Intention. Annals of Tourism Research, 33 (4), 41-58. 